\title{
Histologic evaluation of rats' liver after Croton cajucara Benth (sacaca) administration ${ }^{1}$
}

\author{
Estudo histológico do fígado de ratos após administração de Croton Cajucara Benth \\ (sacaca)
}

\author{
Jair Francisco de Santana Graim", Gaspar de Jesus Lopes Filho"I, Marcus Vinicius Henriques Brito ${ }^{\text {III }}$, Lia Tavares de \\ Moura Brasil Matos ${ }^{\mathrm{IV}}$ \\ ${ }^{I}$ Master, Associate Professor, Integrated Health Department, State University of Pará (UEPA), Brazil. \\ ${ }^{\text {II }}$ Associate Professor, Department of Surgery, Surgical Gastroenterology Division, School of Medicine, Federal University of São Paulo \\ (USP), Brazil. \\ III PhD, Associate Professor, Department of Integrated Health, UEPA, Pará, Brazil. \\ Iv Graduate student.
}

\begin{abstract}
Purpose: To evaluate the hepatic effect of Croton cajucara Benth (sacaca) herbal extract in rats. Methods: 60 Wistar rats (Rattus novergicus albinus) were used, weighing between 250 and $350 \mathrm{~g}$. The animals were distributed randomically in 2 groups: GS - animals which received daily $0,1 \mathrm{ml} / 100 \mathrm{~g}$ of sacaca herbal extract through gavage, and GA -animals which received daily $0,1 \mathrm{ml} / 100 \mathrm{~g}$ of distilled water through gavage. These were distributed in 3 subgroups with 10 animals, according to theirs euthanasia dates, which were 14th, 28th and 56th day of treatment. Results: Architectural alterations were not observed, however when it was analyzed the presence or absence of necrosis, it was observed in 50\% of GS28 subgroup and $90 \%$ of subgroup. In 50\% of the animals from GS28 subgroup and $90 \%$ of GS56 subgroup was observed vast degeneration areas and zonal necrosis, regarding center-lobular veins alterations, there were no alterations in any of the groups Conclusion: The Croton cajucara Benth (sacaca) herbal extract in this experiment caused degeneration and hepatic necrosis, suggesting dose-dependent action.
\end{abstract}

Key words: Plants, Medicinal. Liver. Phytotherapic Drugs. Rats.

\section{RESUMO}

Objetivo: Avaliar histologicamente os efeitos do infuso, por gavagem, do Extrato Bruto Aquoso Seco (EBAS) do Croton cajucara Benth no fígado de ratos. Métodos: Foram utilizados 60 ratos (Rattus novergicus albinus Wistar), pesando entre 250 e $350 \mathrm{~g}$. Os animais foram distribuídos de maneira aleatória em 2 grupos: GS - Grupo de animais que receberam 0,1ml/ $100 \mathrm{~g}$ do infuso de sacaca, pela via oral e GA - Grupo de animais que recebeu $0,1 \mathrm{ml} / 100 \mathrm{~g}$ de água destilada, pela via oral. Estes foram distribuídos em 3 subgrupos de acordo com o dia da eutanásia, sendo esta realizada no $14^{\circ}, 28^{\circ}$ e $56^{\circ}$ dia, cada um com 10 animais. Resultados: Os resultados obtidos demonstraram que, microscopicamente, não houve alterações arquiteturais, porém quando se analisou a necrose hepatocitária, esta esteve presente em 50\% do subgrupo GS28 e $90 \%$ do subgrupo GS56; as alterações inflamatórias puderam ser observadas tanto no subgrupo GS28 como no subgrupo GS56, sendo que neste último se fez presente em $80 \%$, enquanto que no primeiro em apenas $20 \%$ dos animais submetidos ao experimento; $50 \%$ dos animais do subgrupo GS28 e 90\% dos do subgrupo GS56 apresentaram extensa área de degeneração e necrose focal do hepatócito; em 100\% dos animais tanto do GA como do GS não apresentaram qualquer alteração da veia centro-lobular. Conclusão: O infuso de Croton cajucara Benth (sacaca), nas condições deste experimento, foi capaz de determinar degeneração e necrose hepatocitária, sugerindo que a hepatotoxicidade à sacaca é dose dependente.

Descritores: Plantas Medicinais. Fígado. Medicamentos Fitoterápicos. Ratos.

1. Research performed from Experimental Surgery Laboratory, State University of Pará (UEPA), Brazil. 


\section{Introduction}

Croton cajuraca Benth (sacaca), a vegetal specie from Amazon region, is widely used by the local population to treat gastrointestinal conditions, ${ }^{1}$ but it can cause hepatic disfunction, and in some cases fulminant hepatitis., ${ }^{2,3}$

Medicine improvements provided a fantastic growth of drugs currently available to treat and control many diseases. In order to make it possible, scientists, besides developing synthetic drugs, focused into the popular medicine, researching many plants used empirically to treatment of many diseases, aiming the extraction of theirs active principles and the development of new drugs. ${ }^{4,5}$

The popular medicine was sovereign during many centuries, but was replaced, in 20th century, by tested and proven drugs. However population kept faithful to some traditional medicines, even if those are not scientifically proven, as well as it is not known their toxicity, side effects and indications. ${ }^{6,7}$

According to World Health Organization, $80 \%$ of the population uses the popular medicine, because they believe medicinal plants to be an "innocuous" medicine, with less side effects than the allopathic. , $^{89}$

It must be noticed that, to the population nature products are unlikely to cause any harm and it is difficult to resist the seducing promises they offer, as well as its supposed efficacy, and mostly because popular medicine drugs are free or have a low cost, affordable to most of their users. ${ }^{10,11}$

Brazil and specially the Amazon region is considered the widest natural reserve from the planet and still preserve a little of Indians' culture, therefore showing the possibility of a wide use of drugs from natural sources. ${ }^{12,13}$

However, its use must be done carefully, since many of these plants taken as medicines, are highly toxic and many times with unexpected side effects, like hepatitis development caused by sacaca's chronic use, causing death due to that. ${ }^{14}$

The connection between hepatotoxicity and sacaca became notable in the Amazon region, mainly after its commercialization as a medicine to weight and cholesterolemia control. ${ }^{9,15}$

Since sacaca is widely used by population and since it is not fully known its risks, we believe it is necessary to evaluate the microscopic effects of Croton cajucara Benth herbal extract on rats' livers.

\section{Methods}

Sixty Wistar rats (Rattus novergicus albinus), males, adults, weighing between 250 and $350 \mathrm{~g}$, derived from
Evandro Chagas Institute (Belém - Pará) and adapted to the Surgery Experimental Laboratory from State University of Pará (LCE-UEPA) for a period of fifteen days. Animals were kept under standard rodent laboratory housing at conditions with 12 hours day/night cycles and given standard rodent chow diets and tap water ad libitum.

The animals were distributed aleatorically in two groups, according to the substances used:

Sacaca Group (GS): animals which received daily 0,1 $\mathrm{ml} / 100 \mathrm{~g}$ of sacaca herbal extract through gavage.

Water Group (GA): animals which received daily 0,1 $\mathrm{ml} / 100 \mathrm{~g}$ of distilled water through gavage.

Each group was then subdivided in three subgroups each one with 10 animals, according to theirs euthanasia dates, which were 14th, 28th and 56th day of treatment.

\section{Procedures}

The sacaca leaves used in this study were obtained from the Brazilian Agency of Agriculture and Pecuary (EMBRAPA), dehydrated in oven in $45^{\circ} \mathrm{C}$ for 24 hours and grinded to obtain its powder that in the Pharmacology Laboratory from State University of Pará was used to obtain the herbal aquous extract.

Before the gavage the animals were weighed and the dosage of herbal extract calculated. The assigned drugs (water or sacaca) were given to each group at nighttime during 14, 28 or 56 days, according to each subgroup.

In predetermined days, 14th, 28th, and 56th, animals were euthanized by an excessive inhalation of diethylether and their livers were removed. Then, the left lobe was cut in $0,5 \mathrm{~cm}$ slices and put in closed recipients, with tamponated formaldehyde at a 10\% concentration for five days, and sent to the histopathologic processing and analysis.

The microscopic analysis was made with histological cuts of 5 micrometers, counter stained with hematoxilin and eosine, and their reading was made using an optical microscope NIKON-YS2-T.

The data obtained was registered in standardized protocols and analyzed by Fisher's exact test and by chisquare test. $\mathrm{P}$ values $<0.05$ were taken to indicate statistical significance.

\section{Results}

Architectural alterations were present in only one animal from GS56 subgroup (3,3\%). In group GA none of the animals had alterations (Table 1).

TABLE 1 - Presence or absence of architectural alterations in liver cuts of animals treated with water (GA) and sacaca (GS), according to each subgroup

\begin{tabular}{lcccccc}
\hline TREATMENT & \multicolumn{2}{c}{ DAY 14 } & \multicolumn{2}{c}{ DAY 28 } & \multicolumn{2}{c}{ DAY 56 } \\
& presence & absence & presence & absence & presence & absence \\
Water & 0 & 10 & 0 & 10 & 0 & 10 \\
Sacaca & 0 & 10 & 0 & 10 & 1 & 9 \\
\hline
\end{tabular}

Source: Work Evaluation Protocol.

$\mathrm{P}>0,05$ 
When was analyzed the presence or absence of necrosis, it was observed that one animal from the GA28 subgroup presented liver cells necrosis, while half of the animals from GS28 subgroup and almost all from GS56 subgroup had areas of coagulative necrosis (Table 2).

TABLE 2 - Presence or absence of necrosis in liver cuts of animals treated with water (GA) and sacaca (GS), according to each subgroup

\begin{tabular}{lcccccc}
\hline TREATMENT & \multicolumn{2}{c}{ DAY 14 } & \multicolumn{2}{c}{ DAY 28 } & \multicolumn{2}{c}{ DAY 56 } \\
& presence & absence & Presence* & absence & Presence* & absence \\
Water & 0 & 10 & 1 & 9 & 0 & 10 \\
Sacaca & 0 & 10 & 5 & 5 & 9 & 1 \\
\hline
\end{tabular}

Source: Work Evaluation Protocol

$\mathrm{P} *<0,05$ (Qui-quadrado test)

The microscopic analysis from GS28 and GS56 subgroups showed that inflammatory infiltration increases as the time of the drug administrations lengthens, fact that could be observed majorly in GS56 subgroup, where $80 \%$ of the animals had inflammatory alterations (Table 3 ).

TABLE 3 - Presence or absence of inflammatory infiltration in liver cuts of animals treated with water (GA) and sacaca (GS), according to each subgroup

\begin{tabular}{lcccccc}
\hline \multirow{2}{*}{ TREATMENT } & \multicolumn{2}{c}{ DAY 14 } & \multicolumn{2}{c}{ DAY 28 } & \multicolumn{2}{c}{ DAY 56 } \\
& presence & absence & Presence* & absence & Presence* & absence \\
Water & 0 & 10 & 0 & 10 & 0 & 10 \\
Sacaca & 0 & 10 & 2 & 8 & 8 & 2 \\
\hline
\end{tabular}

Source: Work Evaluation Protocol

$\mathrm{P} *<0,05$ (Qui-quadrado test)

In $50 \%$ of the animals from GS28 subgroup and $90 \%$ of GS56 subgroup was observed vast degeneration areas and zonal necrosis, with few inter-cytoplasmatic cholestasis areas and dispersed congestion focus, characterizing drug- induced hepatitis; at the control group, GA28 subgroup, one animal also presented hepatitis, which could be related to a previous hepatic lesion (Table 4).

TABLE 4 - Presence and absence of hepatocellular degenerative alterations in liver cuts of animals treated with water (GA) and sacaca (GS), according to each subgroup

\begin{tabular}{lcccccc}
\hline \multirow{2}{*}{ TREATMENT } & \multicolumn{2}{c}{ DAY 14 } & \multicolumn{2}{c}{ DAY 28 } & \multicolumn{2}{c}{ DAY 56 } \\
& presence & absence & Presence* & absence & Presence* & absence \\
Water & 0 & 10 & 1 & 9 & 0 & 10 \\
Sacaca & 0 & 10 & 5 & 5 & 9 & 1 \\
\hline
\end{tabular}

Source: Work Evaluation Protocol

$\mathrm{P}^{*}<0,05$ (Qui-quadrado test)

Regarding center-lobular veins alterations, there were no alterations in any of the groups (Table 5).

TABLE 5 - Presence or absence of alterations in the center-lobular veins in liver cuts of animals treated with water (GA) and sacaca (GS), according to each subgroup

\begin{tabular}{|c|c|c|c|c|c|c|}
\hline \multirow{2}{*}{ TREATMENT } & \multicolumn{2}{|c|}{ DAY 14} & \multicolumn{2}{|c|}{ DAY 28} & \multicolumn{2}{|c|}{ DAY 56} \\
\hline & presence & absence & Presence* & absence & Presence* & absence \\
\hline Water & 0 & 10 & 0 & 10 & 0 & 10 \\
\hline Sacaca & 0 & 10 & 0 & 10 & 0 & 10 \\
\hline
\end{tabular}

Source: Work Evaluation Protocol 


\section{Discussion}

The Amazonic popular medicine presents many substances with extent indications that were inherited by the Indian culture. Among them, we emphasize sacaca. This specie has registers of many isolated active principles as "dehydrocrotonin, cajucarinolide and isocajucarinolide, cajucarin A and B, diterpene clerodane, linalol", among others. The bark and the leaves of sacaca are used by the population as teas, oil, capsules, pills, extracts, pure or mixed with other substances. ${ }^{2,16,17}$

The quantity of drugs given to each animal was calculated based in data found on the package of medicines sold in pharmacies and adapted to each rat according to the its weight.

The appearance of architectural alterations was an isolated fact, which could correspond to a chronic lesion or a malformation, so there is no intimate relation with the experiment, since architectural alterations in hepatic cells are intimately related to a chronic injury of the organ.

Most of the animals that received sacaca had hepatocellular necrosis that with long term drug administration can determine hepatitis, since the ingestion of drugs through a long period is stated by several authors as being one of the most important factors of hepatic necrosis. ${ }^{18}$ Also, diterpenoids are shown to cause liver injury in animal models, as fully demonstrated on germanderinduced hepatitis. ${ }^{19}$

Inflammatory alterations appear as the drugs' ingestion period lengthens, suggesting the fact that hepatocyte suffering is directly proportional to the drugs' ingestion period. That fact could be easily observed in GS56 group, where $80 \%$ of the animals presented inflammatory alterations.

Large degeneration areas and zonal necrosis were present and it was observed ingurgitated necrotic hepatocyts, with cytoplasmatic and nuclear fragmentation. In most of the cases they were found gathered, sometimes surrounded by leukocitary exsudate that involved isolated hepatocyts or small cellular groups (zonal necrosis), other times involving the entire liver parenchyma (massive necrosis) characterizing drug-induced hepatitis similar to a few other described in the literature. ${ }^{12,20}$

The lack of any alteration in the lobular-center vein suggests that the hepatic alterations produced by sacaca do not have any relation with those produced by viral hepatitis. This is due to the fact in our samples we find a great inflammatory process, while that in the viral hepatitis it is scarce or nonexistent; when it happens, it is localized nearby of center-lobular vein and never on the lobularcenter vein, being totally located in the hepatic zone number three.

\section{Conclusion}

The administration of sacaca herbal extract in this experiment was not able to determine any kind of alteration in rats' livers in 14 days of drug administration. However, when it was used for 28 days, it was possible to observe hepatocellular alterations in some animals used in this experiment. Finally, it was observed that all animals which had the drug for 56 days presented hepatocellular necrosis, similar to acute hepatitis, concluding that the sacaca toxicity is dose-dependent.

\section{References}

1. Hiruma-Lima CA, Toma W, Gracioso JS, Almeida ABA, Batista LM, Magri L, de Paula ACB, Soares FR, Nunes DS, Brito ARMS. Natural transcrotonin: the antiulcerogenic effect of another diterpene isolated from the bark of croton cajucara benth. Biol Pharm Bull. 2002; 25(4):452-6.

2. Itokawa H, Ichiara Y, Shimizu M, Takeya K, Motidome M. Cajucarins A and B, new clerodane diterpenes from Croton cajucara, and their conformations. Chem Pharm Bull. 1990; 38(3):7015.

3. Mincis M. Doença hepática induzida por drogas: aspectos de interesse Clínico. GED Gastroenterol Endosc Dig. 1985; 4(4): 102-8.

4. Tieppo M, Porawski M, Salvador M, Moreira AJ, Collado PS, González-Gallego J, Marroni NP. Croton cajucara benth leaf extract scavenges the stable free radical DPPH and protects against oxidative stress induced by paraquat. Biol Pharm Bull. 2006;29(1):161-5.

5. Lima JMC, Fernandes SG, Alencar ML, Medeiros MTG. Hepatite aguda associada ao uso do Croton cajucara Benth (sacaca): relato de três casos. GED Gastroenterol Endosc Dig. 1999; 18(1): 38.

6. Rodriguez-Garay EA, Larocca C, Pisani G, Del Juan Alvarez M, Rodriguez GP. Adaptive hepatic changes in mild stenosis of the common bile duct in the rat. Res Exp Med. 1999; 198(6): 307-23.

7. Hiruma-Lima CA, Gracioso JS, Nunes DS; Souza Brito AR. Effects of an essential oil from the bark of Croton cajucara Benth on experimental gastric ulcer models in rats and mice. J Pharm Pharmacol. 1999; 51(3): 341-6.

8. Stabnov IM, Neves MS, Freire MAS, Ebecken RFF. Hepatite colestática aguda por sacaca (Croton cajucara). GED Gastroenterol Endosc Dig. 1999; 18(1): 32 .

9. Rodriguez JA, Haun M. Citotoxicity of transdehydrocrotonin from Croton cajucara on V79 cells and rat hepatocytes. Plant MEd. 1999; 65: 522-6.

10. Araujo VC, Correa RGC, Maia JGS, Da Silva ML, Gottlieb OR, Marx MC, Magalhães MT. Óleos essenciais da Amazônia contendo linalol. Acta Amazônica. 1971; 1(3):45-7.

11. Kubo I, Asaka Y, Shibata K. Insect growth inhibitory nor-diterpenes, cis-dehidrocrotonin and trans-dehydrocrotonin, from Croton cajucara. Phytochemistry. 1991;30(8): 2545-6.

12. Fau D, Lekehal M, Farrel G, Moreau A, Moulis C, Feldman G, Haouzi D, Pessayre D. Diterpenoids from Germander, in a herbal medicine, induces apoptosis in isolated rat hepatocytes. Gastroenterology. 1997, 113: 1334-46. 
13. Ichiara Y, Takeia K, Hitosuyanagi Y, Morita H, Okuyama S, Suganuma M, Fujiki HI, Matidome M, Itokawa H. Cajucarinolide and isocajucarinolide: anti-inflammatory diterpenes from Croton cajucara. Planta Med. 1991; 58: 549-51.

14. Brito MVB, Santos MT, Siqueira RBP, Dias CS, Ueno SC, Picanço Junior OM, Carvalho RA. Parâmetros comportamentais e nutricionais de ratos submetidos à administração de sacaca (Croton cajucara, BENTH). Rev Par Med. 2001; 15(3):41-6.

15. Simões JC, Silva AJR, Serruya H, Bentes MHS. Desidrocrotonina, um norditerpeno de Croton cajucara BENTH (Euphorbiaceae). Cienc Cult. 1995;31(10):1140-1.

16. Maciel MAM, Brabo SN, Da Silva MN, Pinto AC. Terpenoids from Croton cajucara. Phytochemistry. 1998; 49(3):823-8.

17. Carvalho JCT, Silva MFC, Maciel MAM, Pinto AC, Nunes DS, Lima RM, Bastos JK, Sarti SJ. Investigation of anti-inflammatory and antinociceptive activies of trans-dehydrocrotonin, a 19-nor-clerodane diterpene from Croton cajucara. Planta Med. 1996; 62: 402-4.
18. Andrade RJ, Robles M, Fernández-Castañer A, López-Ortega S, López-Vega MC, Lucena MI. Assessment of drug-induced hepatotoxicity in clinical practice: a challenge for gastroenterologists. World J Gastroenterol. 2007; 13(3): 329-40.

19. De Berardinis V, Moulis C, Maurice M, Beaune P, Pessayre D, Pompon D, Loeper J. Human microsomal epoxide hydrolase is the target of germander-induced autoantibodies on the surface of human hepatocytes. Mol Pharmacol. 2000;58(3):542-51.

20. Stickel F, Egerer G, Seitz HK. Hepatotoxicity of botanicals. Public Health Nutr. 2000; 3(2):113-24.

\section{Correspondence:}

Jair Francisco de Santana Graim

Av. Nazaré, 444/42

66035-170 Belém-PA Brazil

Jgraim@yahoo.com.br
Conflict of interest: none Financial source: none

Received: September 24, 2007

Review: November 23, 2007

Accepted: December 19, 2007

\section{How to cite this article}

Graim JFS, Lopes Filho GJ, Brito MVH, Matos LTMB. Histologic evaluation of rats' liver after Croton cajucara Benth (sacaca) administration. Acta Cir Bras. [serial on the Internet] 2008 Mar-Apr;23(2). Available from URL: http://www.scielo.br/acb 